\title{
Estimating Technical and Allocative Efficiency in the Public Sector: A Nonparametric Analysis of Dutch Schools
}

Citation for published version (APA):

Haelermans, C., \& Ruggiero, J. (2013). Estimating Technical and Allocative Efficiency in the Public Sector: A Nonparametric Analysis of Dutch Schools. European Journal of Operational Research, 227(1), 172. https://doi.org/10.1016/j.ejor.2012.12.004

Document status and date:

Published: 01/01/2013

DOI:

10.1016/j.ejor.2012.12.004

Document Version:

Publisher's PDF, also known as Version of record

Document license:

Taverne

Please check the document version of this publication:

- A submitted manuscript is the version of the article upon submission and before peer-review. There can be important differences between the submitted version and the official published version of record.

People interested in the research are advised to contact the author for the final version of the publication, or visit the DOI to the publisher's website.

- The final author version and the galley proof are versions of the publication after peer review.

- The final published version features the final layout of the paper including the volume, issue and page numbers.

Link to publication

\footnotetext{
General rights rights.

- You may freely distribute the URL identifying the publication in the public portal. please follow below link for the End User Agreement:

www.umlib.nl/taverne-license

Take down policy

If you believe that this document breaches copyright please contact us at:

repository@maastrichtuniversity.nl

providing details and we will investigate your claim.
}

Copyright and moral rights for the publications made accessible in the public portal are retained by the authors and/or other copyright owners and it is a condition of accessing publications that users recognise and abide by the legal requirements associated with these

- Users may download and print one copy of any publication from the public portal for the purpose of private study or research.

- You may not further distribute the material or use it for any profit-making activity or commercial gain

If the publication is distributed under the terms of Article $25 \mathrm{fa}$ of the Dutch Copyright Act, indicated by the "Taverne" license above, 
Innovative Applications of O.R.

\title{
Estimating technical and allocative efficiency in the public sector: A nonparametric analysis of Dutch schools
}

\author{
Carla Haelermans ${ }^{\mathrm{a}, \mathrm{b}, *}$, John Ruggiero $^{\mathrm{c}}$ \\ a Top Institute for Evidence-Based Education Research (TIER), Maastricht University, Netherlands \\ ${ }^{\mathrm{b}}$ IPSE Studies, Delft University of Technology, Netherlands \\ ${ }^{\mathrm{c}}$ University of Dayton, United States
}

\section{A R T I C L E I N F O}

Article history:

Received 15 May 2012

Accepted 5 December 2012

Available online 20 December 2012

\section{Keywords:}

Data envelopment analysis

Education

Allocative efficiency

\begin{abstract}
A B S T R A C T
Public sector output provision is influenced not only by discretionary inputs but also by exogenous environmental factors. In this paper, we extended the literature by developing a conditional DEA estimator of allocative efficiency that allows a decomposition of overall cost efficiency into allocative and technical components while simultaneously controlling for the environment. We apply the model to analyze technical and allocative efficiency of Dutch secondary schools. The results reveal that allocative efficiency represents a significant 37 percent of overall cost efficiency on average, although technical inefficiency is still the dominant part. Furthermore, the results show that the impact of environment largely differs between schools and that having a more unfavorable environment is very expensive to schools. These results highlight the importance of including environmental variables in both technical and allocative efficiency analysis.
\end{abstract}

(c) 2012 Elsevier B.V. All rights reserved.

\section{Introduction}

Productivity and efficiency of education are topics of intense debate among politicians, teachers, and trade unions and employers in education. Until recently, there was little political discussion on productivity and efficiency in education. However, the EU Lisbon goal of becoming a competitive knowledge economy has put productivity and efficiency high on the political agenda of most countries. In the face of the current economic crisis and the austerity measures and budget cuts that come with that, this goal has become even more of a challenge than before. The challenge is to improve educational output with less or equal money. This puts the productivity and efficiency of education on the agenda.

Responsibility, accountability, and transparency are more and more becoming the norm in education and, therefore, it is important to gain insight in educational productivity and efficiency. First of all, in order to fulfil these requirements, but also because schools are evaluated based on the indicators that are used to measure productivity and efficiency. Schools need to start acting based on the information they get from these indicators in order to be prepared for these assessments. Furthermore, as we want the resources invested in education to be well spent, it is important to operate as

\footnotetext{
* Corresponding author. Address: PO Box 616, 6200 MD Maastricht, Netherlands. Tel.: +31 433884458 .

E-mail address: Carla.Haelermans@maastrichtuniversity.nl (C. Haelermans).
}

efficient as possible, and to generate the highest possible educational output with the given budget.

Lastly, the increasing requirements for schools (e.g., more pupil counseling, additional extra-curriculum activities, use of school buildings during weekends and summer holidays) induce pressure on the resources which are already in place. Productivity is not only a political issue anymore, but has also become an issue in the schools themselves (see Ball and Goldman, 1997; Ministry of Education, 2011a, p. 98).

In this paper, we extend a theoretical framework on technical efficiency and apply it to Dutch secondary schools. Studying Dutch schools is attractive and insightful for three reasons. First, standardized performance measures of Dutch students make educational attainments well comparable. Second, there is information on student achievement, which compares the educational career of a student (both in terms of school track and retentions) with the education track predicted for a student at the end of primary education. Third, Dutch schools receive a yearly lump sum budget from the government, which is at the discretion of the school such that, within the existing legal framework, the allocation of this budget among the several resources is the decision of the school. Therefore, a significant heterogeneity in hired resources, in terms of management, teachers, supporting personnel and material use, is observed.

In the literature, there are many studies on the efficiency of education in which the (average) efficiency scores of the studied schools are presented (e.g. Borge and Naper, 2006; Chakraborty 
et al., 2001; Cordero-Ferrera et al., 2008; Grosskopf et al., 2009; Korhonen et al., 2011; Ouellette and Vierstraete, 2005). Some authors make a comparison between two groups of institutions, e.g. from different countries, and draw a conclusion related to the difference in efficiency scores between these groups (e.g. Barbetta and Turati, 2003; Grosskopf et al., 2009). However, most of the efficiency studies look at different units of observation, and conclude that efficiency scores vary greatly among the units of observation (Barbetta and Turati, 2003).

These studies on efficiency in education differ widely, both with respect to content and methodology. The content differs mostly in the types of inputs and outputs used in the measurement of productivity. With respect to outputs, some studies use only the number of students of certain years (e.g. Ouellette and Vierstraete, 2005), whereas other studies use the number of students and the subsequent student performance (e.g. Blank et al., 2007). There are also studies that use only the student performance or changes in student performance as an output measure (e.g. Afonso and St. Aubyn, 2006; Conroy and Arguea, 2008; Korhonen et al., 2011; Millimet and Collier, 2008). Studies using at least student performance, that can be independently compared and cannot be influenced by the schools, as output measure, are preferable over studies using, for example, only student numbers as output. One reason is that in most countries schools are evaluated based on student performance and not on the number of students. Another reason is that such an independent performance measure is comparable and cannot be influenced.

With respect to inputs, studies use costs of personnel or materials (e.g. Grosskopf et al., 1997), costs per student (e.g. Chakraborty et al., 2000; Haelermans and De Witte, 2012; Ruggiero, 2007), total costs of a school (e.g. Aaltonen et al., 2006), or costs including prices (e.g. Haelermans and Blank, 2012; Haelermans et al., 2012). Other studies do not use costs as inputs, but use, for example, the number of teachers (e.g. Barbetta and Turati, 2003), teacher characteristics (such as experience, Conroy and Arguea, 2008), school characteristics, parental information (such as income level, educational facilities at home and contribution of the parents towards to school programs Korhonen et al., 2011), or student characteristics. Studies using costs and prices combined with the number of students and teachers as inputs are preferable over studies that use other inputs. A reason for the preference for including costs and prices is that in many countries schools receive a lump sum payment and are evaluated based on their performance. Another reason is that a combined input of both costs and prices and number of students or teachers provides more information than using only costs.

Besides differences in content, there are methodological differences between efficiency studies. These methodological differences between efficiency studies do not necessarily influence the quality of the studies, but do influence the outcomes and interpretation of the results. The most important methodological distinction is the difference between studies using parametric methods, such as stochastic frontier analysis (e.g. De Witte et al., 2010; Grosskopf et al., 2009) and studies using nonparametric methods, such as data envelopment analysis or free disposal hull (e.g. Haelermans and De Witte, 2012). There is also a methodological difference between studies using a cost function or input oriented analysis (e.g. Denaux, 2009), and studies using a production function or output oriented analysis (e.g. Haelermans and Blank, 2012; Haelermans et al., 2012).

The measure of allocative efficiency yields insights in the underor over-utilization of school resources. Allocative efficiency in primary or secondary education has been largely overlooked. The available allocative efficiency studies mostly consider higher education (Cherchye and Vanden Abeele, 2005; Johnes and Johnes, 2009; Soares de Mello et al., 2006; Tauer et al., 2007). Some rare exceptions are Banker et al. (2004) and Grosskopf et al. (1997, 2001) both of which study school districts in Texas.
However, in many cases the environment plays a large role in the performance of the school, but this is often ignored. This paper contributes to the literature by extending the theoretical model and explicitly taking into account an (un)favorable environment to the school, which influences its technical and allocative efficiency. We use a nonparametric analysis, with costs and FTEs (Full Time Equivalents) per personnel group as inputs and three types of student performance as outputs. The share of students from a disadvantaged area is used as the environmental variable.

The remainder of this paper is organized as follows. In the next section, we present the public sector DEA model that properly controls for nondiscretionary inputs. In this section we also develop a new model to allow estimation of cost efficiency in the presence of these exogenous factors and provide a decomposition of overall cost inefficiency into technical and allocative components while controlling for the operating environment. In Section 3, we apply our model to analyze technical, allocative and cost efficiency of Dutch schools using 2007 data. The results indicate that although technical inefficiency is the dominant type of inefficiency, allocative inefficiency is a significant component of overall inefficiency. The last section concludes the paper.

\section{Public sector production and costs}

We assume that each of $n$ schools uses a vector $X=\left(x_{1}, \ldots, x_{m}\right)$ of $m$ discretionary inputs to produce a vector $Y=\left(y_{1}, \ldots, y_{s}\right)$ of $s$ outputs while facing an environment characterized by index $z$ and exogenous input prices $P=\left(p_{1}, \ldots, p_{m}\right)$. Observed production and price data for school $j(j=1, \ldots, n)$ are given by $X_{j} \equiv\left(x_{1 j}\right.$, $\left.\ldots, x_{m j}\right), Y_{j}=\left(y_{1 j}, \ldots, y_{s j}\right), P_{j}=\left(p_{1 j}, \ldots, p_{m j}\right)$ and $z_{j}{ }^{1}$ Given observed inputs and prices, observed expenditures $\left(E_{j}\right)$ for school $j(j=1, \ldots, n)$ is $E_{j}=\sum_{l=1}^{m} p_{l j} x_{l j}$. We specify the empirical production possibility set as:

$T(z)=\{Y, X, z): \sum_{j=1}^{n} \lambda_{j} y_{k j} \geqslant y_{k} \geqslant 0, \quad k=1, \ldots, s ;$

$\sum_{j=1}^{n} \lambda_{j} x_{l j} \leqslant x_{l}, \quad l=1, \ldots, m$

$\sum_{j=1}^{n} \lambda_{j}=1$

$\lambda_{j}=0$ if $z_{j}>z \geqslant 0, \quad j=1, \ldots, n$,

$\lambda_{j} \geqslant 0, \quad j=1, \ldots, n$.

The technology in (1) allows variable returns to scale for any given level of the environmental variable in the standard sense of changing the scale of operation with respect to the discretionary inputs. Also, we assume that output is monotonic with respect to the environmental index; larger values of $z$ imply a favorable operating environment where the school should produce at least as much output for any given mix of discretionary inputs. ${ }^{2}$

Based on (1), Ruggiero (1996) developed a DEA model to estimate technical efficiency of school $i(i=1, \ldots, n)$ as the solution to the following linear program:

\footnotetext{
${ }^{1}$ Here, we simply exposition to assume there is only one nondiscretionary factor. In the case of multiple nondiscretionary variables, we can employ a multiple stage model to construct an index of environmental influence. See the Appendix for discussion. Our technology description is consistent with our empirical analysis, which uses only one nondiscretionary input.

2 An anonymous referee correctly points out that our modeling works if we have resource prices for all discretionary inputs. In the case when some discretionary input does not have a price and a shadow price cannot be imputed, we are left with measuring only technical efficiency unless we make additional assumptions. This is consistent with the motivation of Charnes et al. (1978) who argue for using technical efficiency in the public sector where prices might not be available.
} 


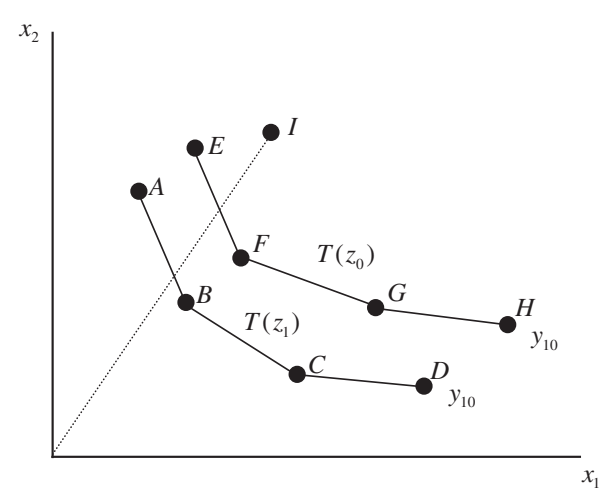

Fig. 1. Production with non-discretionary inputs.

$T E_{i}=\operatorname{Min} \theta$

s.t.

$$
\begin{aligned}
& \sum_{j=1}^{n} \lambda_{j} y_{k j} \geqslant y_{k i}, \quad k=1, \ldots, s \\
& \sum_{j=1}^{n} \lambda_{j} x_{l j} \leqslant \theta x_{l i}, \quad l=1, \ldots, m ; \\
& \sum_{j=1}^{n} \lambda_{j}=1 \\
& \lambda_{j}=0 \text { if } z_{j}>z_{i}, \quad j=1, \ldots, n \\
& \lambda_{j} \geqslant 0, \quad j=1, \ldots, n .
\end{aligned}
$$

Here, the frontier is defined for each level of the non-discretionary input assuming variable returns to scale with respect to the discretionary inputs. As discussed in Podinovski (2005), this model relaxes convexity assuming only selective convexity for a given level of the nondiscretionary input.

We illustrate the public sector production model in Fig. 1, where it is assumed that nine schools $A-I$ use two discretionary inputs $x_{1}$ and $x_{2}$ to produce output level $y_{10}$ while facing nondiscretionary input $z$. The diagram is consistent with the quasi-fixed inputs presented in Anandalingam and Kulatilaka (1987). We assume that schools $A-H$ are technically efficient, producing the observed level of output with the minimum level of inputs for their discretionary input mix. As shown, schools $E-H$ face a harsher environment $\left(z_{0}<z_{1}\right)$ and are required to use more discretionary inputs to produce the same level of output as schools $A-D$.

School $I$, observed producing $y_{10}$, is technically inefficient. If $I$ faces the harsher environment with nondiscretionary input level $z_{0}$, (2) properly compares $I$ to a convex combination of $E$ and $F$. Likewise, if school $I$ has nondiscretionary input level $z_{1}$, the appropriate benchmark for $I$ would be a convex combination of $A$ and $B$.

Model (2) was developed as an alternative to the Banker and Morey (1986) model for exogenous inputs, which forced convexity with respect to both discretionary and nondiscretionary inputs. In public sector applications like education, this assumption of convexity with respect to the nondiscretionary inputs might not be valid. Model (2) estimates efficiency by comparing a given school to only those schools with no better environment. ${ }^{3}$

We extend the public sector model (2) for technical efficiency estimation to measure cost efficiency and its technical and allocative components in the presence of nondiscretionary inputs. With

\footnotetext{
${ }^{3}$ Given the nature of the constraints on the nondiscretionary inputs, the estimates of efficiency are consistent; however, the model requires a relatively larger sample size. The curse of dimensionality arises with multiple nondiscretionary inputs. Ruggiero (1998) provides an extension of Ray (1991) to alleviate this problem. See the appendix for further discussion.
}

the production technology given in (1), we now consider the minimum cost of producing a given output vector. For school $i(i=1, \ldots, n)$ which faces exogenous input prices $P_{i}=\left(p_{1 i}, \ldots, p_{m i}\right)$ and environment $z_{i}$ the minimum cost $C_{i}$ of producing $Y_{i}=\left(y_{1 i}\right.$, $\left.\ldots, y_{s i}\right)$ is found as the solution of the following linear program:

$$
\begin{array}{ll}
C_{i}^{*}= & \operatorname{Min} \sum_{l=1}^{m} p_{l i} x_{l} \\
\text { s.t. } & \\
& \sum_{j=1}^{n} \lambda_{j} y_{k j} \geqslant y_{k i}, k=1, \ldots, s ; \\
& \sum_{j=1}^{n} \lambda_{j} x_{l j} \leqslant x_{l}, l=1, \ldots, m ; \\
& \sum_{j=1}^{n} \lambda_{j}=1 ; \\
& \lambda_{j}=0 \text { if } z_{j}>z_{i}, j=1, \ldots, n ; \\
& \lambda_{j} \geqslant 0, \quad j=1, \ldots, n .
\end{array}
$$

Unlike the models of technical efficiency that identify discretionary input reduction, in model (3) we solve for the optimal input vector $X_{i}^{*}=\left(x_{1 i}^{*}, \ldots, x_{m i}^{*}\right)=\left(x_{1}^{*}, \ldots, x_{m}^{*}\right)$ for school $i$ that minimizes the cost of producing the observed output subject to the environmental conditions and exogenous prices. We now define the level of cost efficiency for school $i$ as:

$C E_{i}=\frac{\sum_{l=1}^{m} p_{l i} x_{l i}^{*}}{\sum_{l=1}^{m} p_{l i} x_{l i}}=\frac{C_{i}^{*}}{E_{i}}$,

i.e., the ratio of minimum costs to observed spending on discretionary inputs.

We illustrate public sector costs in Fig. 2, where we maintain the assumptions on the technology in Fig. 1. In this case we assume that school $I$ faces the harsher environment $z_{0}$, with the technology defined by the convex hull of schools $E-H$. School $I$ is observed spending $E_{I}$ on discretionary inputs. If school $I$ became technically efficient, it could reduce its spending to $E_{I}^{*}=T E_{I} \cdot E_{I}$ the value of the technical inefficiency of school $I$ (i.e., waste due to technical inefficiency) is $E_{I}-T E_{I} \cdot E_{I}=\left(1-T E_{I}\right)$. There is additional waste, however, resulting from not using the proper mix of inputs. Given the technology and the observed input price ratio, school $I$ could minimize costs by operating at point $F$, leading to a minimum cost of $C_{I}^{*}$ and a cost efficiency index of $C E_{I}=\frac{C_{I}^{*}}{E_{I}}$. Overall, school $I$ is spending $E_{I}-C_{I}^{*}$ above the minimum cost of which $C_{I}^{*}-E_{I}^{*}$ is the value of allocative inefficiency arising from not using the cost minimizing mix of inputs.

Finally, we can now consider the effect that the environment has on optimal input mix and the associated minimum costs. For school $i(i=1, \ldots, n)$ which faces exogenous input prices $P_{i}=\left(p_{1 i}\right.$, $\ldots, p_{m i}$ ) and environment $z_{i}$ we solve (3) without the constraint on the nondiscretionary inputs:

$$
\begin{aligned}
& C_{i}^{* *}=\operatorname{Min} \sum_{l=1}^{m} p_{l i} x_{l} \\
& \text { s.t. } \\
& \qquad \sum_{j=1}^{n} \lambda_{j} y_{k j} \geqslant y_{k i}, \quad k=1, \ldots, s ; \\
& \quad \sum_{j=1}^{n} \lambda_{j} x_{l j} \leqslant x_{l}, \quad l=1, \ldots, m ; \\
& \quad \sum_{j=1}^{n} \lambda_{j}=1 ; \quad \lambda_{j} \geqslant 0, \quad j=1, \ldots, n .
\end{aligned}
$$

The solution to (5) reveals the minimum cost for school $i$ if the school had the most favorable environment. Importantly, for schools that have to compensate bad environments with additional 
discretionary inputs to produce a given output vector, the solution to (5) will not be feasible. The solution to (5), together with the solution to (3), shows how much additional expenditures are necessary to compensate for the environment; we define environmental costs for school $i(i=1, \ldots, n)$ as:

$E C_{i}=C_{i}^{*}-C_{i}^{* *}$,

i.e., the difference in costs between the conditional (3) and unconditional models (5). Note that the efficiency score obtained from (5) can never be greater than the efficiency score obtained from (3).

In Fig. 3, we illustrate the environmental costs for school $I$ by extending Fig. 2. Here, we continue the assumption that school $I$ faces the harsh environment. As discussed above, the minimum cost of producing $y_{10}$ with the harsh environment is $C_{I}^{*}$; if school $I$ faced the better environment represented by $z_{1}$, it could have produced the same output with minimum costs $C_{I}^{* *}$. Consequently, the environmental costs facing school $I$ is $E C_{I}=C_{I}^{*}-C_{I}^{* *}$. An interesting result emerges in the solution of (3) and (5) regarding the optimal input mix: the optimal mix on inputs for a given input price vector depends on the environment. School I should use relatively more $x_{2}$ than it would if it had the more favorable environment. This is seen by noting for school $I$ that the ratio $x_{2} / x_{1}$ is higher in the solution to (3) at point $F$ than it is in the solution to (5) at point $C$.

\section{Efficiency in Dutch schools}

In this section we describe the data and apply our models to analyze technical, allocative and cost efficiency of Dutch schools.

\subsection{Dutch secondary education}

Dutch secondary education offers four different levels of education, which are concluded with a national examination in the last year. Students enter a level of education based on a recommendation given in elementary school. Secondary education takes 4,5 or 6 years to complete, depending on the level of education. The first 3 years of secondary education are called lower secondary education. The last 1, 2 or 3 years of secondary education are considered upper secondary education. Most schools offer a combination of these four levels of education, but some only offer one of these levels and are considered specialized schools.

Secondary schools in the Netherlands receive a lump sum payment from the government every year. Within the existing legal framework, the allocation of this budget among the several resources is the decision of the school. Note that the lump sum budget excludes (large and discontinuous) payments on housing infrastructure (these are provided by the municipal and central government). In most cases the municipality is responsible for

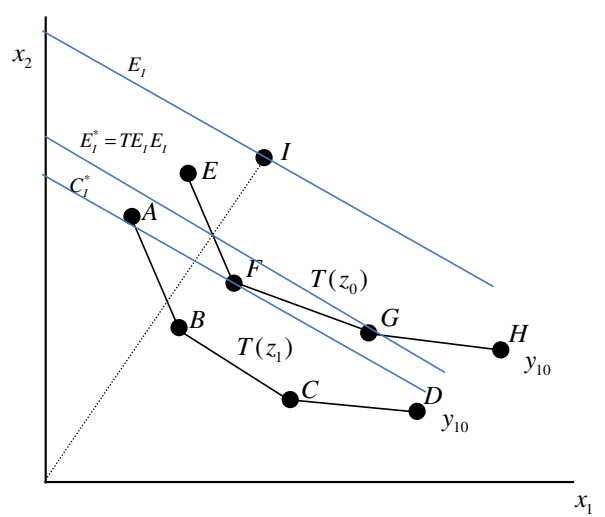

Fig. 2. Cost efficiency with non-discretionary inputs.

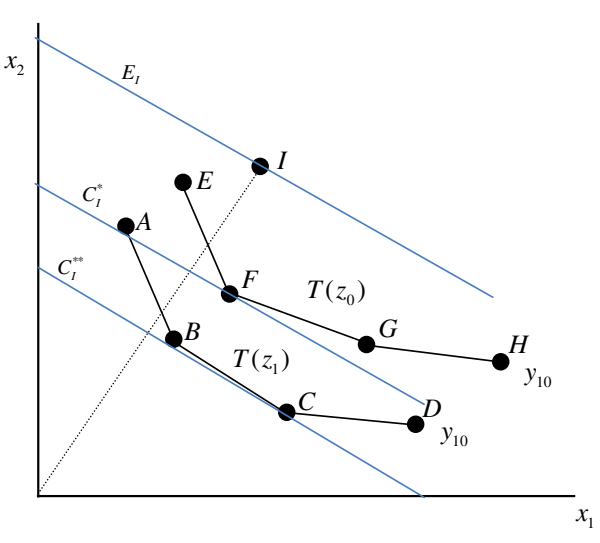

Fig. 3. Non-discretionary inputs and optimal input mix.

the accommodation of the school. However, the school itself is responsible for the maintenance of the building. In practice, this means that the school is granted a certain amount from the municipality to fulfill this responsibility.

\subsection{Data}

We use a representative dataset of 448 Dutch secondary schools covering the school year 2007/2008. For convenience, we refer to this school year as 2007. The data are obtained from several existing administrative data sets from the Ministry of Education, the Education Inspectorate and Statistics Netherlands.

\subsubsection{Production}

Educational production is commonly defined as some kind of measure of educational attainments in knowledge and skills (Wenger, 2000). We use three measures for educational production: the average student national examination grades per school, the average student achievement each year during secondary education and the total number of students. The first serves as a proxy for attainments, while the second and third for educational quality.

With respect to the first, every graduating student undertakes this test at the end of secondary education for the subjects the student is registered. The exams are graded in a double blind way and the school and the teacher of the students cannot directly influence the outcome of the exams. ${ }^{4}$ The average grade per school is based on the average of all national examination grades for all students in all subjects. Note that the level of analysis is the school and not the subject or the student.

To proxy the quality of the educational process, we include the total number of students and a composite number of Education Inspectorate: average aggregated corrected achievement. This number compares the educational track of a student in a given year with the education track predicted for a student at the end of primary education. An aggregated corrected achievement of 1 denotes that all students are exactly in the year and level of education they are predicted to be according to primary education test results. Summary statistics are provided in Table 1 .

Table 1 shows that the average national examination grade amounts to 6.4 on a 10 point scale. A 5.5 is sufficient to pass the subject. The grades range from 5.4 to 7.2 . Despite the larger variation, the standard error is relatively low. Student achievement has an average of 0.832 and the total number of students is on average 1744 per school.

${ }^{4}$ School might be able to indirectly influence exam results on an abstract level as they may, for example, be teaching to the test. However, as the exams are nationally developed and cannot directly be influenced by the school, we assume independence of these results 


\subsubsection{Resources}

School resources are summarized along four relatively homogeneous categories: (1) management personnel, (2) teaching personnel, (3) supporting personnel and (4) material supplies. 'Capital' in the sense of housing infrastructure is not accounted for due to data constraints. For the human resources (the first three groups), data are available on full time equivalents (FTE) and costs. In particular, the costs correspond to the costs per FTE per year. The total average number of FTE per school equals 163, consisting for 80 percent out of teachers, 14 percent of supporting personnel and the remaining 6 percent of managing personnel. The total costs of a school are about 12 million Euro per year. The majority of the costs are spend on teaching personnel, followed by materials, managing personnel and, finally, supporting personnel. Besides teaching, a teacher has some management and administrative duties. The different tasks within one function are not officially reported. We assume that there is a homogeneous distribution of these different tasks within one function, both between teachers within one school and across schools.

The wage of teachers, school management and supporting personnel is, a priori, similar for all schools in the Netherlands, as a teacher with a given experience and a certain age would earn a similar wage across all schools. Therefore, we expect prices to be comparable and use the reported expenses spend on the different personnel types per school.

\subsubsection{Exogenous variable}

Some influences are exogenous to the school and create heterogeneity across schools. In this paper we include the share of students from a disadvantaged neighborhood as exogenous variable. Previous research has shown the importance of including this exogenous variable (Becker and Luthar, 2002; Gaziel, 1997).

The share of students from a disadvantaged neighborhood amounts, on average, to 2.7 percent. However, this number varies between schools from 0 to 20 percent.

\subsection{Results}

Table 2 presents the results for the efficiency indices, the waste measures and the input mix. Table 2 shows that, although allocative inefficiency is a significant component of overall inefficiency, technical inefficiency is still the dominant type of inefficiency. Table 2 shows that the overall average cost efficiency is 77 percent, whereas the average technical and allocative efficiency are 85 and 90 percent, respectively. Furthermore, we can see from Table 2 that the waste measures in Euros from the total inefficiency amount to almost 3 million Euro, of which about two third is due to technical inefficiency and the remainder one third to allocative inefficiency. This implies that, if schools would operate optimally efficient, they could save millions of Euros per year. Furthermore, Table 2 shows that a more negative environment, i.e. more stu- dents from a disadvantaged neighborhood, costs schools 2.6 million Euro on average, compared to if they would have had the best environment possible. However, the large standard deviations show that there is a large dispersion between schools in the amount of money that could be saved.

Lastly, Table 2 shows the current input mix and the optimal input mix for the average Dutch secondary school. Table 2 shows that optimally, schools have 12 teachers for 1 manager and 4 teachers for 1 support personnel member. However, in reality we see that schools have about 17 teachers for one manager and 6 teachers for 1 support personnel member. From this we can conclude that (1) schools employ too many teachers and could improve efficiency by firing some teachers, and (2) schools should hire more support personnel. Note that not all tasks in a school have to be fulfilled by teachers in order to maintain educational quality. For example, supervision of a group of students in selfstudy, the support and coaching of student projects or supervision during lunch time can be undertaken by support personnel (see e.g. Blatchford and Sumpner, 1998).

However, in practice schools rarely have full possibilities to change their work force, as employees are protected by permanent contracts and/or other social security laws. Dutch schools could, however, gradually change their workforce by taking advantage of the natural turnover and the aging of the baby boomers (the cohort born after World War II), which accelerates the outflow (Ministry of Education, 2011b). Similar to the waste measures, for the observed and optimal input mixes we also observe very high standard deviations, again showing the large differences between schools.

Table 3 presents similar results to Table 2, but now for each quintile of the environmental harshness separately. The first quintiles represent the best environment, whereas the fifth quintile represents the worst environment. In Table 3 we clearly see a difference in the influence of the environment on the waste measures and on the optimal input mix. There is no clear pattern visible in the technical, allocative and cost efficiencies of the five quintiles. With respect to the efficiencies, we see that the first quintile has the highest overall cost efficiency, whereas interestingly the second quintile has the lowest efficiency. Schools in the fifth quintile could improve their allocative efficiency most, whereas schools in the second quintile could improve their technical efficiency most. Overall, there is still a lot to gain for schools with the least favorable environment (fifth quintile), as their average cost efficiency waste measures in Euros are almost 5 million, compared to almost 2 million for schools that have the most favorable environment.

Similar to what Table 2 showed, here we also see that schools have too many teachers, no matter to which quintile they belong. However, we do see that schools in the first quintile, for example, have the second largest ratio of teachers to manager, whereas the optimum numbers show that they should have the lowest. Both in the case of the ratio of teachers to managers as teachers to support personnel, Table 3 shows that schools in the fifth quintile have the

Table 1

Descriptive statistics.

\begin{tabular}{|c|c|c|c|c|}
\hline & Mean & Standard deviation & Minimum & Maximum \\
\hline Students & 1741.426 & 993.274 & 158.000 & 5971.000 \\
\hline National examination & 6.378 & 0.217 & 5.443 & 7.229 \\
\hline Student achievement & 0.833 & 0.061 & 0.571 & 1.067 \\
\hline Management personnel (FTE) & 8.705 & 6.595 & 0.300 & 43.843 \\
\hline Teachers (FTE) & 130.901 & 80.455 & 15.190 & 468.315 \\
\hline Support personnel (FTE) & 23.339 & 15.491 & 2.779 & 119.456 \\
\hline Material expenses (1000s of Euros) & 2248.822 & 1606.143 & 138.731 & 12409.444 \\
\hline Average management price & 88807.43 & 28552.85 & 19375.23 & 231924.87 \\
\hline Average teacher price & 67576.17 & 16130.49 & 38581.24 & 155061.41 \\
\hline Average support personnel price & 21255.81 & 7964.19 & 10405.93 & 93086.69 \\
\hline Economically disadvantaged students (\%) & 2.631 & 3.025 & 0.000 & 19.664 \\
\hline
\end{tabular}

All prices in Euros. 
Table 2

Efficiency results.

\begin{tabular}{lll}
\hline & Mean & Standard deviation \\
\hline Efficiency indices & & \\
Technical & 0.858 & 0.123 \\
Allocative & 0.903 & 0.089 \\
Cost & 0.774 & 0.133 \\
Waste measures (in Euros) & & \\
Technical inefficiency & $1,770,324$ & $1,815,503$ \\
Allocative inefficiency & $1,046,726$ & $1,370,063$ \\
Cost inefficiency & $2,817,050$ & $2,388,262$ \\
Environmental costs & $2,613,406$ & $2,461,475$ \\
Input mix observed & & \\
Teacher: Management & 17.50 & 9.91 \\
Teacher: Support personnel & 6.19 & 2.82 \\
Teacher: Material expenses & 63.05 & 19.83 \\
Input mix optimal & & \\
Teacher: Management & 12.35 & 5.95 \\
Teacher: Support personnel & 3.73 & 1.61 \\
Teacher: Material expenses & 35.53 & 9.74 \\
\hline
\end{tabular}

Calculations by authors. Material expenses are measured in 1000s of Euros.

highest ratio. In the case of the teacher manager ratio, they also have the highest optimum. Schools in the fifth quintile have both the highest observed and highest optimum ratio of teachers compared to material expenses. This might imply that students at these schools might need more guidance from their teachers, whereas students from schools in, for example, the first quintile, might need more materials to be able to work independently. Lastly, Table 3 shows that schools in the fifth quintile has one of the lowest ratios of teachers to support personnel. This implies that these schools need relatively more support personnel than other schools, which also points at the extra guidance and support that the students at these schools might need. The clear difference between the quintiles shows the difference in student population between schools in, e.g., the first and the last quintile. Schools in the fifth quintile can improve their efficiency by almost 5 million Euros, but they do need more teachers and more support personnel to teach their students and make them perform well. Table 3 shows the importance of including the environmental harshness of the school. Showing the information for the different quintiles shows the large differences between schools and the different implications that a different environment has for the optimum input mix of a school.

\section{Conclusions}

In this paper, we measure technical efficiency using a conditional DEA estimator that controls for the exogenous operating environment. We extended this model with a conditional DEA estimator of allocative efficiency that allows a decomposition of overall cost efficiency into allocative and technical components while simultaneously controlling for the environment. For illustrative purposes, we apply the model to analyze technical and allocative efficiency of Dutch secondary schools. Our results indicate that allocative inefficiency is a large share of cost inefficiency, although technical inefficiency is still the dominant part. Furthermore, the results show that having a more unfavorable environment costs schools millions of Euros each year. A separate analysis for the five quintiles of environmental harshness reveals the differences between schools that have a different environment, both with respect to finances as with respect to the optimum input mix. These results highlight the importance of including environmental variables in both technical and allocative efficiency analysis.

We believe that the theoretical extension developed in this paper provides a useful foundation for analyzing technical and allocative efficiency in the public sector, where the technology set is influenced by the socioeconomic environment. A useful extension of this work would be a focus on the policy implications; in particular, given limited governmental resources, what are the sources of technical and allocative inefficiency in the public sector and how can overall efficiency be improved by reallocating input mixes according to socioeconomic conditions.

For future research, we would suggest to study the Dutch schools participating in the TIMMS study, similar to Korhonen et al. (2011). An advantage of using the TIMMS data is that environmental factors that could be worth studying can be incorporated. Disadvantage is that it is impossible to use costs as inputs and study the cost efficiency. Furthermore, it would be interesting to apply this model to data on schools in different countries, to be able to compare the difference in impact of the environmental factors between countries.

\section{Appendix A}

Per the request of an anonymous referee, we show the extension of our approach to the case of multiple environmental variables. We now assume that each of $n$ schools faces a vector $Z=\left(z_{1}, \ldots, z_{r}\right)$ of $r$ environmental variables; each school $j(j=1, \ldots, n)$ faces environment $Z_{j} \equiv\left(z_{1 j}, \ldots, z_{r j}\right)$. We maintain the same notation for all other variables described in Section 2 . The conditional convexity model introduced by Ruggiero (1996) suffers the curse of dimensionality because it is unable to properly weight the importance of each environmental variable on overall production. Hence, as the number of environmental variables increases, the probability that a school is identified as efficient by default increases because the sample of possible benchmark decreases. Ruggiero (1998) extended the conditional convexity model with a three-stage model. In this appendix, we show this extension for our model in which we estimate both technical and allocative efficiency.

In the first stage, we solve a composed model similar to (2) that excludes the conditional constraints on the environmental variables. The resulting first-stage index of $\operatorname{school} i(i=1, \ldots, n)$ is found as the solution to the following linear program:

$F S_{i}=\operatorname{Min} \theta$

s.t

$$
\begin{aligned}
& \sum_{j=1}^{n} \lambda_{j} y_{k j} \geqslant y_{k i}, \quad k=1, \ldots, s ; \\
& \sum_{j=1}^{n} \lambda_{j} x_{l j} \leqslant \theta x_{l i}, \quad l=1, \ldots, m ; \\
& \sum_{j=1}^{n} \lambda_{j}=1 ; \\
& \lambda_{j} \geqslant 0, \quad j=1, \ldots, n .
\end{aligned}
$$

Because the constraints on the environment have been removed, the resulting index is composed of inefficiency and the effect that the environmental variables have on production. Ray (1991) proposed a second stage multiple regression model to factor out the environmental effect:

$F S=\alpha+\sum_{k=1}^{r} \beta_{k} z_{k}+\varepsilon$

where the residual is the measure of efficiency. ${ }^{5}$ Note that the resulting residual, however, is mean zero. Ruggiero (1998) extended

\footnotetext{
5 Ray (1991) used OLS while McCarty and Yaisawarng (1993) applied Tobit. Banker and Natarajan (2008) showed that OLS provides consistent estimates while McDonald (2009) argued that tobit is not appropriate, arguing in favor of either OLS or fractional logit. Estelle et al. (2010) used nonparametric regression and tested the choice of regression models using all four regressions. The models provided nearly identical results.
} 
Table 3

Average results by environmental harshness.

\begin{tabular}{|c|c|c|c|c|c|}
\hline & \multicolumn{5}{|l|}{ Quintile } \\
\hline & 1 & 2 & 3 & 4 & 5 \\
\hline \multicolumn{6}{|l|}{ Efficiency indices } \\
\hline Technical & 0.902 & 0.807 & 0.833 & 0.886 & 0.862 \\
\hline Allocative & 0.916 & 0.907 & 0.906 & 0.912 & 0.874 \\
\hline Cost & 0.826 & 0.732 & 0.755 & 0.808 & 0.754 \\
\hline \multicolumn{6}{|l|}{ Waste measures (in Euros) } \\
\hline Technical inefficiency & $1,044,074$ & $1,642,395$ & $1,554,458$ & $1,721,897$ & $2,886,834$ \\
\hline Allocative inefficiency & 848,311 & 633,594 & 873,179 & $1,044,762$ & $1,829,171$ \\
\hline Cost inefficiency & $1,892,385$ & $2,275,990$ & $2,427,637$ & $2,766,660$ & $4,716,004$ \\
\hline \multicolumn{6}{|l|}{ Input mix observed } \\
\hline Teacher: Management & 18.08 & 15.59 & 16.27 & 17.49 & 20.02 \\
\hline Teacher: Support personnel & 6.56 & 5.91 & 5.71 & 6.05 & 6.72 \\
\hline Teacher: Material expenses & 64.89 & 65.68 & 64.90 & 61.67 & 58.13 \\
\hline \multicolumn{6}{|l|}{ Input mix optimal } \\
\hline Teacher: Management & 13.70 & 8.45 & 10.47 & 14.13 & 14.98 \\
\hline Teacher: Support personnel & 4.76 & 3.03 & 3.41 & 3.82 & 3.63 \\
\hline Teacher: Material expenses & 32.96 & 30.36 & 32.54 & 35.97 & 45.79 \\
\hline
\end{tabular}

Calculations by authors. Material expenses are measured in 1000s of Euros.

this to a third-stage by recognizing that regression provides the proper weights $\beta_{k}(k=1, \ldots, r)$ to identify trade-offs between environmental factors. Hence, we can define an overall index of environmental harshness for each school $i(i=1, \ldots, n)$ that can be used in the third stage ${ }^{6}$ :

$\hat{z}_{i}=\sum_{k=1}^{r} \beta_{k} z_{k i}$

After obtaining the index of environmental harshness, we can now solve for cost efficiency using model (3) and obtain the rest of the measures discussed in Section 2:

$$
C_{i}^{*}=\operatorname{Min} \sum_{l=1}^{m} p_{l i} x_{l}
$$

s.t.

$$
\begin{aligned}
& \sum_{j=1}^{n} \lambda_{j} y_{k j} \geqslant y_{k i}, \quad k=1, \ldots, s ; \\
& \sum_{j=1}^{n} \lambda_{j} x_{l j} \leqslant x_{l}, \quad l=1, \ldots, m ; \\
& \sum_{j=1}^{n} \lambda_{j}=1 ; \\
& \lambda_{j}=0 \text { if } \hat{z}_{j}>\hat{z}_{i}, \quad j=1, \ldots, n ; \\
& \lambda_{j} \geqslant 0, \quad j=1, \ldots, n .
\end{aligned}
$$

\section{References}

Aaltonen, J., Krirjavainen, T., Moisio, A., 2006. Efficiency and Productivity in Finnish Comprehensive Schools in 1998-2004. Vatt Research Reports, No. 127.

Afonso, A., St. Aubyn, M., 2006. Cross-country efficiency of secondary education provision: a semi-parametric analysis with non-discretionary inputs. Economic Modelling 23, 476-491.

Anandalingam, G., Kulatilaka, N., 1987. Decomposing production efficiency into technical, allocative and structural components. Journal of the Royal Statistic Society A 150, 143-151.

Ball, C.G., Goldman, S., 1997. Improving education's productivity: reexamining the system to get the schools we need. Phi Delta Kappan 78 (3), 228-232.

\footnotetext{
${ }^{6}$ The benefit of the three-stage model over Ray (1991) is the resulting index of efficiency that maintains the standard properties. In addition, the three stage model, unlike Ruggiero (1996) does not require a priori determination of the direction of influence each environmental variable has on production. Simulations in Ruggiero (1998) show, however, that Ray (1991) performs equally well with respect to ranking of inefficient units.
}

Banker, R.D. Janakiraman, S., Natarajan, R., 2004. Analysis of trends in technical and allocative efficiency: an application to Texas public school districts. European Journal of Operational Research 154, 477-491.

Banker, R.D., Morey, R.C., 1986. Efficiency analysis for exogenously fixed inputs and outputs. Operations Research 34 (4), 513-521.

Banker, R.D., Natarajan, R., 2008. Evaluating contextual variables affecting productivity using data envelopment analysis. Operations Research 56 (1), 48-58.

Barbetta, G.P., Turati, G., 2003. Efficiency of junior high schools and the role of proprietary structure. Annals of Public and Cooperative Economics 74 (4), 529551.

Becker, B.E., Luthar, S.S., 2002. Social-emotional factors affecting achievement outcomes among disadvantaged students: closing the achievement gap. Educational Psychologist 37 (4), 197-214.

Blank, J.L.T. Koot, P.M. van Hulst, B.L, 2007. Overhead of Onderwijs - Een benchmark van de allocatie van middelen in onderwijsinstellingen voor voortgezet onderwijs. IPSE Studies/ECORYS, Delft/Rotterdam.

Blatchford, P., Sumpner, C., 1998. What do we know about breaktime? Results from a national survey of breaktime and lunchtime in primary and secondary schools. British Educational Research Journal 24 (1), 79-94.

Borge, L.E., Naper, L.R., 2006. Efficiency potential and efficiency variation in Norwegian lower secondary schools. FinanzArchiv 62 (2), 221-249.

Chakraborty, K., Biswas, B., Lewis, W.C., 2000. Economies of scale in public education: an econometric analysis. Contemporary Economic Policy 18 (2) 238-247.

Chakraborty, K., Biswas, B., Lewis, W.C., 2001. Measurement of technical efficiency in public education: a stochastic and nonstochastic production function approach. Southern Economic Journal 67 (4), 889-905.

Cherchye, L., Vanden Abeele, P., 2005. On research efficiency. A micro-analysis of Dutch university research in Economics and Business Management. Research Policy 34, 495-516.

Conroy, S.J., Arguea, N.M., 2008. An estimation of technical efficiency for Florida Public elementary schools. Economics of Education Review 27, 655-663.

Cordero-Ferrera, J.M., Pedraja-Chaparro, F., Salinas-Jiménez, J., 2008. Measuring efficiency in education: an analysis of different approaches for incorporating non-discretionary inputs. Applied Economics 40, 1323-1339.

De Witte, K., Groot, W., Maassen van den Brink, H., 2010. The Efficiency of Education in Generating Literacy: A Stochastic Frontier Approach. TIER Working Paper Series 10/17.

Denaux, Z.S., 2009. Determinants of technical efficiency: urban and rural public schools in the state of Georgia. Southwestern Economic Review 26 (1), 105-115.

Gaziel, H.H., 1997. Impact of school culture on effectiveness of secondary schools with disadvantaged students. The Journal of Educational Research 90 (5), 310 318 .

Grosskopf, S., Hayes, K.J., Taylor, L.L., 2009. The relative efficiency of charter schools Annals of Public and Cooperative Economics 80 (1), 67-87.

Grosskopf, S., Hayes, K.J., Taylor, L.L., Weber, W.L., 1997. Budget-constrained frontier measures of fiscal equality and efficiency in schooling. Review of Economics and Statistics 79 (1), 116-124.

Grosskopf, S., Hayes, K.J., Taylor, L.L., Weber, W.L., 2001. On the determinants of school district efficiency: competition and monitoring. Journal of Urban Economics 49 (3), 453-478.

Haelermans, C., Blank, J.L.T., 2012. Is a schools' performance related to educational change? - a study on the relation between innovations and secondary school productivity. Computers and Education 59 (3), 884-892.

Haelermans, C., De Witte, K., 2012. The role of innovations in secondary school efficiency: evidence from a conditional efficiency model. European Journal of Operational Research 223, 541-549. 
Haelermans, C., De Witte, K., Blank, J.L.T., 2012. On the allocation of resources for secondary schools. Economics of Education Review 31 (5), 575-586.

Johnes, G., Johnes, J., 2009. Higher education institutions' costs and efficiency: taking the decomposition a further step. Economics of Education Review 28, 107-113.

Korhonen, P., Soleimani-damaneh, M., Wallenius, J., 2011. Ratio-based RTS determination in weight-restricted DEA models. European Journal of Operational Research 215, 431-438.

McCarty, T.A., Yaisawarng, S., 1993. Technical efficiency in New Jersey School Districts. In: Fried, H.O., Lovell, C.A.K., Schmidt, S.S. (Eds.), The Measurement of Productive Efficiency. Oxford University Press, New York.

McDonald, J., 2009. Using least squares and Tobit in second stage DEA analyses. European Journal of Operational Research 197, 792-798.

Millimet, D.L., Collier, T., 2008. Efficiency in public schools: does competition matter? Journal of Econometrics 145, 134-157.

Ministry of Education, 2011a. Kerncijfers 2006-2010. Ministry of Education, Culture and Science, Den Haag.

Ministry of Education, 2011b. Nota werken in het onderwijs 2011. Ministry of Education, Science and Culture, Den Haag.

Ouellette, P. Vierstraete, V., 2005. An evaluation of the efficiency of Québec's school boards using the data envelopment analysis method. Applied Economics 37, 1643-1653.
Podinovski, V., 2005. Selective convexity in DEA models. European Journal of Operational Research 161, 552-563.

Ray, S.C., 1991. Resource-use efficiency in public schools: a study of Connecticut data. Management Science 37 (12), 1620-1628.

Ruggiero, J., 1996. On the measurement of technical efficiency in the public sector. European Journal of Operational Research 90, 553-565.

Ruggiero, J., 1998. Non-discretionary inputs in data envelopment analysis. European Journal of Operational Research 111, 461-469.

Ruggiero, J., 2007. Measuring the cost of meeting minimum educational standards: an application of data envelopment analysis. Education Economics 15 (1), $1-13$.

Soares de Mello, J.C.C.B., Goncalves Gomes, E., Angulo Meza, L., Soares de Mello, M.H.C., Soares de Mello, A.J.R., 2006. Engineering post-graduate programmes: a quality and productivity analysis. Studies in Educational Evaluation 32, 136152.

Tauer, L.W., Fried, H.O., Fry, W.E., 2007. Measuring efficiencies of academic departments within a college. Education Economics 15 (4), 473-489.

Wenger, J.W., 2000. What do schools produce? Implications of multiple outputs in education. Contemporary Economic Policy 18 (1), 27-36. 